\title{
An analysis of potential investment returns of planted forests in South China
}

\author{
Pu Zhang ${ }^{1} \cdot$ Youjun $\mathrm{He}^{2} \cdot$ Yiming Feng ${ }^{1} \cdot$ Rafael De La Torre $^{3} \cdot$ Hongyan Jia $^{4}$. \\ Jixin Tang ${ }^{5}$. Frederick Cubbage ${ }^{6}$
}

Received: 5 May 2018 / Accepted: 19 February 2019 / Published online: 4 March 2019

(C) The Author(s) 2019

\begin{abstract}
Financial returns of forest plantations are an important concern around the world. In this research, we focused on South China's timber investments, collected data from the Pingxiang, Guangxi Province, China, which is the demonstration zone of Fast-growing and High-yielding Timber Plantation Base Construction Program and National Timber Strategic Storage and Production Bases Construction Program, and used capital budgeting analysis method and sensitivity analysis to compare different scenarios of planted forest management. The results showed that excluding land costs, (1) the financial returns of Eucalyptus forest managed by small business were excellent, having an IRR of $28 \%$ per year and a LEV of $\$ 7555$ per ha, but it had a high risk with fluctuations of cost, timber price and timber yield; (2) the results for the Experimental Center of Tropical Forests indicate that the Eucalyptus forest and Castanopsis hystrix forest returns were greater than those for Cunninghamia lanceolata forest and Pinus massoniana forest, with having IRRs of 24\%,21\%, 13\% and 10\% per year respectively. The mixed planted forest of Castanopsis hystrix $\times$ Eucalyptus and Castanopsis hystrix $\times$ Pinus massoniana had the features of high profits and low risks; (3) the forest farmers had lower levels of returns for Eucalyptus forest management in South China, but were still in the middle rank of global comparisons. This study gave a view of China's timber investment and provided more options of improving the economic returns of planted forest management to both small businesses and forest farmers in South China.
\end{abstract}

Keywords China $\cdot$ Planted forest $\cdot$ Economics $\cdot$ Investment returns

Electronic supplementary material The online version of this article (https://doi.org/10.1007/s 1105 6-019-09708-x) contains supplementary material, which is available to authorized users.

Frederick Cubbage

cubbage@ncsu.edu

Extended author information available on the last page of the article 


\section{Introduction}

Financial returns from planted forests are one of the most important business decisions for reliable future returns around the world (Cubbage et al. 2007, 2010; Wang et al. 2014). From 1990 to 2015, the world total area of planted forests increased from 167.5 to 277.9 million hectares or $4.06 \%$ to $6.95 \%$ of total forest area (Macdicken et al. 2015). As the most populated country of the world, China has made extraordinary efforts in developing planted forests during the past decades (Zhang and Song 2006). In 2015, there were 78.9 million ha of planted forest in China which accounted for $28.4 \%$ of the world's total planted forest area or $33.33 \%$ of the China's forest area. Cunninghamia lanceolata, Populus spp., Eucalyptus spp., Larix gmelinii and Pinus massoniana were China's main tree species of planted forest (Liu et al. 2014).

China has substantial opportunities to increase timber production in the future (Payn et al. 2015). There are some important policies promoting the further increase:

The first policy is the Natural Forest Protection Program (NFPP), which was implemented by the Chinese government in 1998 and was aimed at protecting the forest ecosystem, and strengthening eco-conservation. It strictly prohibited commercial logging of natural forests (Bai et al. 2015) and indirectly guaranteed the area growth of planted forests that potentially support natural forest conservation (Ainembabazi and Angelsen 2014; Secco and Pirard 2015). This program gradually changed the center of timber production from state-owned natural forests in North China to planted forests in South China.

The second policy is Fast-growing and High-yielding Timber Plantation Base Construction Program (2002) which was intended to solve the problem of China's timber and forest products supply. Wood consumption in China has undergone tremendous increases as a result of a booming economy ( $\mathrm{He}$ and $\mathrm{Xu} 2011)$. Nevertheless, its domestic timber production was nearly constant from 2005 to 2014. The huge gap between consumption and production reached to 51.19 million $\mathrm{m}^{3}$ in 2014 (Forestry Statistics Almanac 2015). Of all logs and lumber imported into Asia in 2013, China's imports accounted for $71 \%$ and $47 \%$ respectively (Sewall 2014). This program has constructed many plantation bases for different kinds of forest productions, such as paper pulp, wood-based panel and large diameter logs. The planted forests in southern China are increasing in importance.

The third policy is the National Timber Strategic Storage and Production Bases Construction Program, which emphasized forming a timber resources system for back-up, with basically proper mix and relatively optimized structure of tree species, in order to reduce the imbalance between supply and demand of domestic timber (SFA 2013a). Implemented in 2012 , this program planned to increase the timber supply by 100 million $\mathrm{m}^{3}$ over the following 10 years.

The fourth policy is Collective Forest Tenure reform (2003) which began to reduce the scope of collective management and increase the share of individual management (forest farmers) without changing the legal ownership, providing for more diverse planted forest management entities (Qin et al. 2011). Two types of forestland ownership co-exist in China: state ownership, which is most prevalent in North China and village collective ownership, which dominates in South China (Jiang et al. 2014). Collectively-owned forests accounted for 58\% of China's total forest area and 32\% of total timber volume (SFA 2013b). By 2011, the property rights of 168 million ha (92\%) of collective forest land had been clarified and about 82 million households had received forestland certificates (FAO 2013). Some farmers began to pay attention to forest land management, while some farmers transferred their forest land to companies or individuals who want to manage on a large scale. In Guangxi province in South 
China, there were more than 1000 small business owners whose forestland was more than 30 ha (Shaoming and Zheng 2006).

These forestry policies gave the investment of planted forests in China its own characteristics. The planted forests in South China were more important than before. Fast-growing and high-yielding plantations became more popular in South China. Furthermore, the planted forest investment from forest farmers and the private sector were motivated after the Collective Forest Tenure Reform. A diversity of planted forests management entities in South China were developed.

A number of articles have examined the investment returns of planted forests around the world. Some focused on a large set of countries and compared advantages among these countries. Sedjo $(1983,2001)$ calculated average investment returns for selected plantation species (Pinus spp., Eucalyptus spp., Pseudotsuga menziesii and Picea abies) in USA, Brazil, Chile, New Zealand, South Africa and Europe. Cubbage et al. (2007, 2010, 2014) compared plantation financial returns from countries in tropical, subtropical, and temperate areas of North and South America, Asia, and Oceania, used exotic species, primarily Pinus spp. and Eucalyptus spp. Some examined the investment returns for individual species or countries. Xin-Min et al. (2001) analyzed economic performance of Pinus massoniana forest for pulpwood in South China. Liao et al. (2009) investigated the financial performance of investments in timberland and timber and their correlations with nonforestry financial assets in the United States. Some studies focused on one to three species with different management modes in a certain research area. Maraseni et al. (2017) compared the financial returns from acacia plantations with different plantation densities and rotation ages in Vietnam. Salek and Sloup (2012) evaluated the pure and mixed stands in Central Vietnam high lands. A few other studies estimated timber investment returns for different management entities. Frey et al. (2018) compared the profitability of state forest enterprises plantations and smallholder forest plantations in Vietnam. Wang et al. (2014) analyzed of potential investment returns and their determinants of poplar plantations in state-owned forest enterprises of China. However, there is relatively little literature provided comprehensive knowledge and detail information of the South China planted forests investment.

This research focused on South China's planted forests investments and extended analyses to complex details, such as different management entities (state-owned forest managed by state, collective-owned forest managed by small business, and collective-owned forest managed by forest farmers); different tree species (Cunninghamia lanceolata, Pinus massoniana, Eucalyptus and Castanopsis hystrixh); and different management modes (pure forest and mixed forest). We collected data from Pingxiang, Guangxi Province, China, and used the cost-benefit analysis method and sensitivity analysis to compare different scenarios of planted forest management.

The objectives were to: (1) evaluate the investment returns of planted forests; (2) compare the economic benefit of different tree species and management modes, and the efficiency of different management entities; and (3) calculate sensitivity coefficients and summarize the risks among these scenarios. This research can provide information about plantation forest management in South China, and help forest farmer, small business and state forest enterprises in South China make forest investment decisions. 


\section{Materials and methods}

\section{Study area}

This research's study area, Pingxiang County, is located in Guangxi Province in Southwest China. Pingxiang County has a subtropical monsoon climate, ranging geographically from $106^{\circ} 41^{\prime}$ to $106^{\circ} 59^{\prime} \mathrm{E}$ and $21^{\circ} 57^{\prime}$ to $22^{\circ} 16^{\prime} \mathrm{N}$, characterized by wide seasonal variations in rainfall (the annual rainfall in the region is $1200-1500 \mathrm{~mm}$ ), high temperatures (the annual average temperature varies between $20.5^{\circ} \mathrm{C}$ and $21.7^{\circ} \mathrm{C}$ ) and high humidity (the relative humidity is $80-84 \%$ ) (Jiang et al. 2015). The soil at the study area was formed from granite and is classified as red soil in the Chinese soil classification, showing $\mathrm{pH}$ value of 4.8-5.5 (Youjun et al. 2013).

The planted forest management in Pingxiang County is typical of that in South China. Most kinds of planted forest management ownership types, most of planted forest species and planted forest management methods exist there. Private forestry sector in Pingxiang County largely operates as part of the South China timber market (Bai et al. 2015; Dai et al. 2013). The state forest enterprises in Pingxiang County as all the state forest enterprises in South China are government-controlled.

\section{Management regimes}

We collected data by identifying the most common and important forest species and management regimes from three kinds of planted forest management entities in the region (Table 1). The data were standardized by means of the Excel spreadsheets adapted from Cubbage et al. (2007, 2010, 2014), and adjusted to include relevant management activities and costs. The Excel template is available as supplementary information in Cubbage's article (2014). The approach in the template and its capital budgeting formulas are described here.

The spreadsheet was a template with cells for species, planting and management costs, timber productivity, and timber returns, which were then used to calculate various capital budgeting metrics. The costs include all relevant forest regeneration, intermediate stand treatments and management, costs for taxes, and administration for every scenario. We collected data from a government research forest and from surveys of forest business owners and forest farmers in South China. From these research records and surveys, we chose ten species and management combinations, with typical data as the base case to produce the most representative management, cost, and return scenarios.

The cost, timber price and timber yield were the key factors influencing the returns of timber investment in China (Huang 2007; Song-Hai et al. 2016). Thus, each management regime would have these three variables with three levels (lower, basic, and higher levels) and thus 27 combinations of inputs analyzed (Table 2). This then generated groups of present value and rate of return, which indicated the range and more likely capital budgeting results.

\section{The Experimental Center of Tropical Forests (ECTF)}

The Experimental Center of Tropical Forests (ECTF) is a typical state-owned forest farm in South China that has strong research funding and scientific capacity. Owning about 16,000 ha of forests, ETCF has had experience of managing planted forests, which 


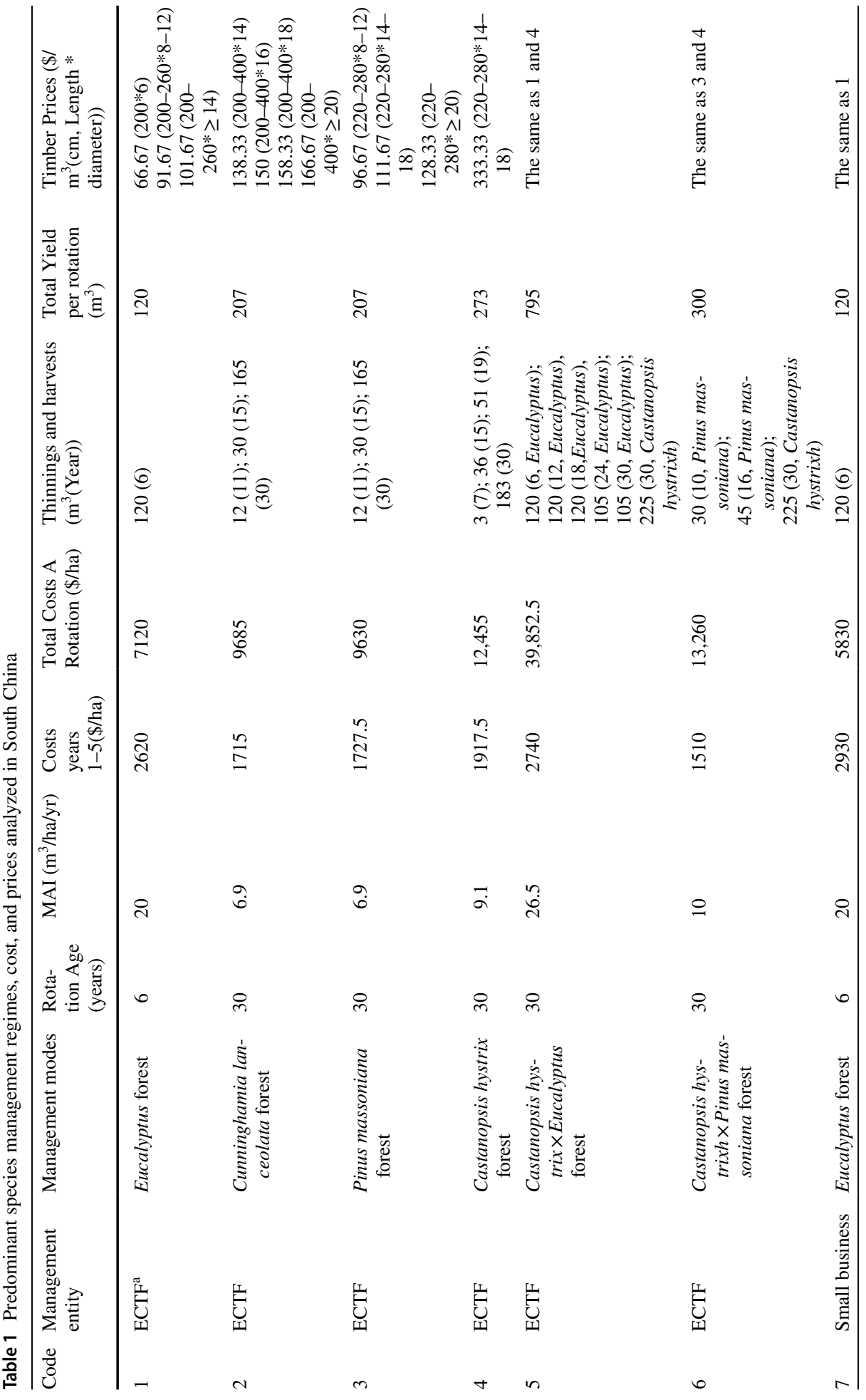




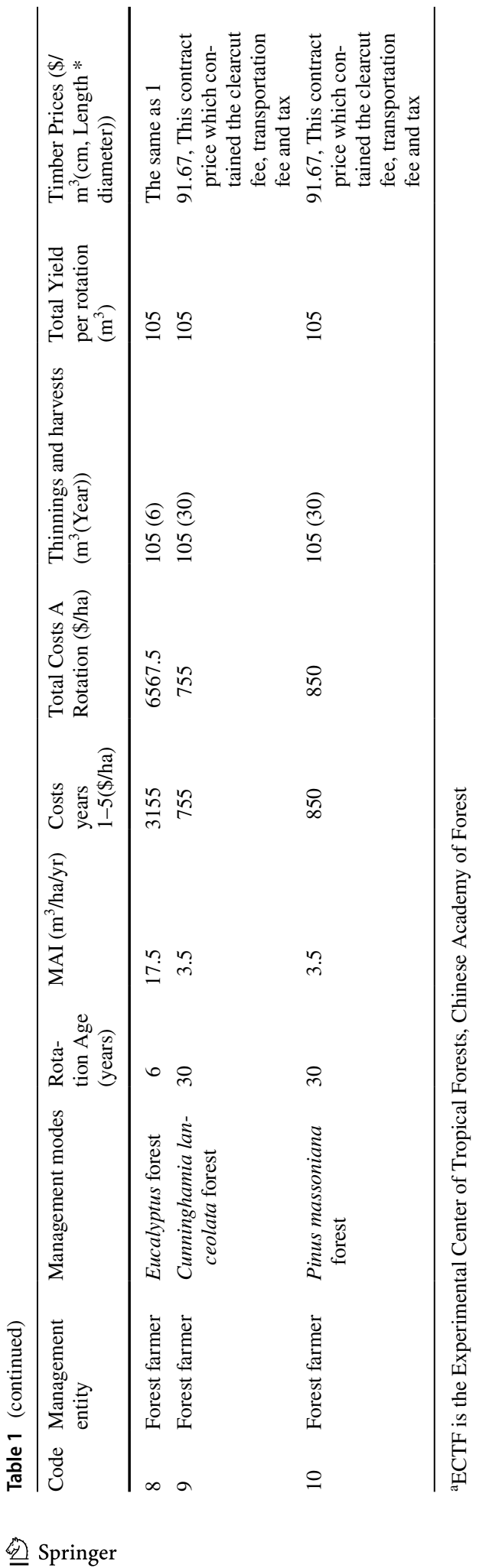




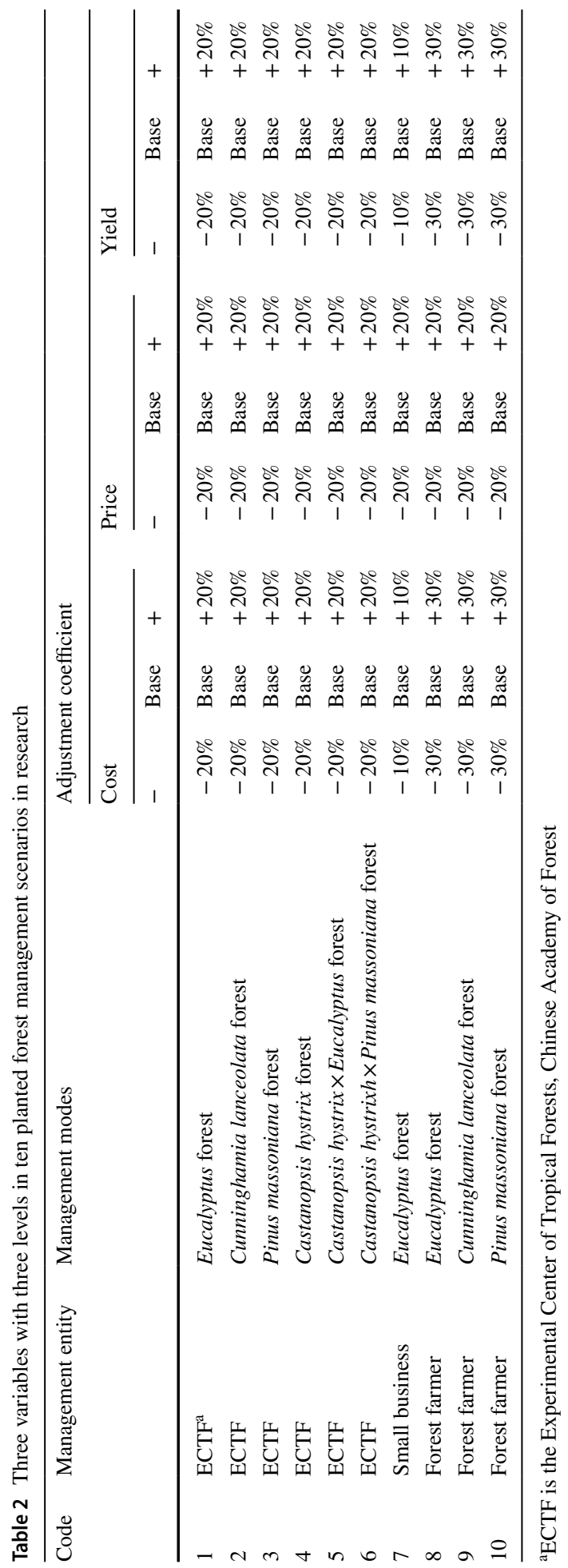


provided necessary data. This research focused on its six planted forest management models, which were their primary management models (Table 1).

The research materials are provided by the forest management department, ECTF, including the productive investment cost list (forestation, young growth tending, sanitation cutting, thinning, clear cutting, transportation, fire control, roads and disease control etc.), timber price list, timber harvest list, and related data from 2011 to 2013.

The data for six scenarios managed by ECTF in 2013 as the base were available as supplementary information upon request. Considering the data in 2011 and 2012 and the individual differences among each piece of forestland, for all the six scenarios managed by ECTF, the total cost was adjusted by $\pm 20 \%$, the timber price by $\pm 20 \%$ and timber yield by $\pm 20 \%$. Although the cost, timber prices and timber yield of different scenarios for ECTF varied, we used the same adjustment coefficient for each factor, which could represent the overall volatility.

\section{Small business}

After the Collective Forest Tenure Reform, one consequence had been the fragmentation of forestlands (Zhen et al. 2018). Small business owners began to aggregate holdings in order to improve the economies of scale in forest management and reduce the fragmentation of forestland (Zhen et al. 2018). They gathered forestland by transferring the forestland from individual farmer households whose management rights of forestland were clarified after the reform (Xu and Jiang 2009).

We interviewed three small businesses who managed more than 60 ha of forest land in Pingxiang County and collected their cost and benefit data in 2013. They chose the pure Eucalyptus forest as their main management mode (Table 1). For the typical regime, small businesses paid land rents for 10 years or 15 years before the planting activities, and divided the management process to small parts, and contracted them to different professional teams. In the first year, they prepared the seedlings and contracted out the afforestation. The contractors got payment under the condition that the survival rate of the Eucalyptus forest reached 95\% 1 month after planting. The timber harvest and transportation were contracted out together and paid according to how many cubic meters they had to harvest.

We chose this typical one as the base. Considering the data from the other two small businesses, we adjusted the total cost by $\pm 10 \%$. The timber price and adjustment followed the ECTF's because they share the same market. Timber yield was adjusted by $\pm 10 \%$ according to the survey results (Table 2).

\section{Forest farmers}

After the Collective Forest Tenure Reform, forest farmers were given the rights for forestland management and forest tree ownership, and afforestation by individual farmer households increased significantly (Xu and Jiang 2009). However, one initial consequence of this reform was the fragmentation of forestlands (Zhen et al. 2018), with each member household being assigned approximately 1.8 ha of forestland in South China (Hou et al. 2013). Thus the owners must strive to cooperate in management and in harvesting to achieve enough volume to make operations economically practical.

In this research, we carried out a face-to-face questionnaire survey to 198 forest farmer households in 9 villages in Pingxiang Guangxi Province in 2013. According to this survey, the main management modes were Cunninghamia lanceolata, forest planted by $39 \%$ of 
these forest farmers; Pinus massoniana forest was planted by $34 \%$ of the forest farmers; and Eucalyptus forest planted by $14 \%$ of the forest farmers.

Cunninghamia lanceolata and Pinus massoniana were the main tree species in previous afforestation movement launched by the local government in Pingxiang County in 1980s. These two tree species were chosen by most of local forest farmers in the following years. In recent years, the small business began to plant the Eucalyptus forest around the forestland of forest farmers and obtained higher economic returns, causing some of the forest farmers to change the tree species in their forestland.

We chose planted forests of these three species and used data collected from the typical forest farmers who represented the average management level in this area.

Forest farmers' Cunninghamia lanceolata forest and Pinus massoniana forest were under extensive management. Most forest farmers only invested in the first 3 years and didn't participate in the management in the following years until the harvest time. The timber price used in this analysis is the contract price, which contained clearcut fee, transportation fee and tax. There was no capital cost for using one's own forest land. For the management of Eucalyptus forest, the forest farmers invest more than what with the other two tree species. The Eucalyptus stumpage timber price here was the market price.

We adjusted the basic data according to ranges found in the survey. The cost was adjusted by $\pm 30 \%$, the timber price by $\pm 20 \%$ and the timber yield by $\pm 30 \%$ (Table 2 ).

\section{Capital budgeting analysis}

There are many methods to calculate returns of planted forest investment. Evison (2018) summarized the essentially two methods-some "analyses use stock market data on timberlands companies" (Ibbotson and Sinquefield 1976), and others collect typical data on costs revenues and yields so that an estimate of return can be calculated using discounted cash flow analysis and capital budgeting criteria (Ben-Horin and Kroll 2017), such as net present value (NPV), land expectation value (LEV) and internal rate of return (IRR) which were often used as indicators for assessing economic returns of planted forest (Cubbage et al. 2007, 2010; Keča et al. 2012; Klemperer 1996; Wagner 2012). In addition, Cubbage et al. (2014) and Wang et al. (2014) had used NPV, LEV and IRR to evaluate the investment returns of planted forests in China and compared the results with other countries. The respective formulas follow:

$$
\begin{gathered}
N P V=\sum_{n=0}^{N} \frac{B_{n}}{(1+i)^{n}}-\sum_{n=0}^{N} \frac{C_{n}}{(1+i)^{n}} \\
L E V=N P V+\frac{N P V}{(1+i)^{N}-1}
\end{gathered}
$$

IRR: $i$ such that

$$
\sum_{n=0}^{N} \frac{B_{n}}{(1+i)^{n}}=\sum_{n=0}^{N} \frac{C_{n}}{(1+i)^{n}}
$$

where: $n=$ year number, $B_{n}=$ benefit in year $\mathrm{n}, C_{n}=$ cost in year $\mathrm{n}, i=$ annual discount rate, $N=$ lifetime of project or rotation length. 
Net Present Value (NPV) is the difference between the present value of cash inflows and the present value of cash outflows at a selected discount rate (Eq. 1). NPV is used as one of the primary indicators for project evaluation (Keča et al. 2012; Rocha 1973; Tee et al. 2014). It is generally recommended as one preferred criterion in most forest economics textbooks (Klemperer 1996; Wagner 2012) and particularly useful with relatively shortterm forestry investments, such as fast-grown species (Cubbage et al. 2013).

Land Expectation Value (LEV) is the extension of NPV into perpetuity for long-lived forestry investments of unequal time lengths (Eq. 2) (Cubbage et al. 2013). It was proposed by Faustmann in 1849 and is still quite widely adopted (Tee et al. 2014). A positive LEV indicates that one could pay that amount for the land and still receive a certain real rate of return at the designated discount rate.

Riskiness in the investment and time value of money are generally captured by the discount rate, which is assumed to be constant throughout the forest's lifetime (Tee et al. 2014). In China, the real interest rate was 3-4\%; the inflation rate was $2-3 \%$ (National Bureau of Statistics 2014). The forest risk was 1\% (Wang 2010). The range of nominal discount rates in forestry department is calculated by adding real interest rate, inflation rate and forest risk together, which was 6-8\%. In previous researches about China's forestry, discount rate was chosen between 4 and 12\% (Chen 2001; Chen et al. 2002; Xin-Min et al. 2001). Cubbage et al. $(2007,2010,2014)$ used a discount rate of $8 \%$ in their global timber investment research. Considering the characteristics of China's forestry and prior research, we used $8 \%$ real discount rate to estimate returns for all scenarios in this research.

The Internal Rate of Return (IRR) is a discount rate that makes the Net Present Value (NPV) of all cash flows from a particular project equal to zero. IRR calculations rely on the same formula as NPV does (Eq. 3). Often owners do not know their discount rate, so IRR provides a means of comparing investments intuitively with the implied cost of capital. IRR avoids problems of project scale or length in making comparisons (Cubbage et al. 2013). IRR often is used as a proxy for annual returns in the forest finance literature, making it comparable to other asset class analyses.

\section{Sensitivity analysis}

In this research, we used a sensitivity coefficient (the same as the Elasticity which is the measurement of how responsive an economic variable is to a change in another) to value the IRR and LEV fluctuation associated with the cost, timber price and timber yield for all the planted forest management scenarios. All the IRRs and LEVs of each scenario calculated above were grouped according to the new category (variables' worst-, base- and bestcase, and each group had 9 IRRs or LEVs, Table 5). By comparing each IRR and LEV in worst-case with that in base-case, and IRR and LEV in best-case with that in base-case, we got two groups of sensitivity coefficients for each variable (Eq. 4, Table 6) in each management scenario. The formula follows:

$$
S_{\text {nik }}=\frac{\left(A_{\text {nik }}-A_{\text {niBase }}\right) / A_{\text {niBase }}}{\left|i_{\text {nik }}-i_{\text {niBase }}\right| / i_{\text {niBase }}}
$$

where: $S=$ Sensitivity coefficient, $A=\mathrm{IRR}$ or LEV, $n=$ Code of management scenario; $\mathrm{n}=1.2 \ldots 0.10, i=$ cost, price and yield, $k=-$, Base, + . 
After that we used the Wilcoxon signed-rank test to find out the $F S_{\text {nik }}$ (final sensitivity coefficient) in each group. This test was proposed by Frank Wilcoxon in 1945 and was especially appealing when dealing with financial data that defies the assumptions imposed by parametric methods (Taheri and Hesamian 2013). The null hypothesis of this test is that the $S_{n i k}$ s in one group were no more than (for the best-and base-case comparison) or no less than (for the worst- and base-case comparison) $T S_{n i k}$ (test sensitivity coefficient). We change $T S_{n i k}$ until the $P$ value of a one-sided test turned out to be less than the 0.05 significance level, then we reject the null hypothesis and see this $T S_{n i k}$ as $F S_{n i k}$ (Table 7).

\section{Results}

Table 3 summarizes the capital budgeting results on basic levels for the 10 management regimes, which are shown in Figs. 1 and 2 as the band inside the box (the median) as well. Table 4 shows the variability of IRRs and LEVs of Eucalyptus forest managed by the ECTF depending on the assumptions in Table 2. These IRRs and LEVs contributed to the first boxes in Figs. 1 and 2. The similar extensive data for the other nine management regimes are available as supplementary information by request via email from the first or last authors. The final results of all management regimes are showed in the Figs. 1 and 2.

\section{The IRRs of three management entities}

Greater IRRs indicate preferred investments based on these financial criteria. We used IRR as one of two key metrics to compare the ten scenarios because the forestland in China was owned by state or collectively. These entities were capital owners who pay the rent to have the right to manage the planted forest rather than land owners who buy the forestland in timber investment activities. Figure 1 indicate the base return values (the median) for each regime, as well as the maximum and minimum values (the whiskers) and the $25 \%$ range on each side of mean (the box).

Excluding land costs, the financial returns of Eucalyptus forest managed by small business were excellent, having an IRR of $28 \%$ per year which was the maximum value among

Table 3 Capital budgeting results for the base case and levels for selected species management regimes analyzed in South China (without the land price)

\begin{tabular}{llllr}
\hline Code & Management entity & Management modes & IRR $_{\text {Base }}(\%)$ & LEV $_{\text {Base }}$ \\
\hline 1 & ECTF $^{\mathrm{a}}$ & Eucalyptus forest & 24 & 5321.14 \\
2 & ECTF & Cunninghamia lanceolata forest & 13 & 2419.41 \\
3 & ECTF & Pinus massoniana forest & 10 & 947.92 \\
4 & ECTF & Castanopsis hystrix forest & 21 & $13,194.39$ \\
5 & ECTF & Castanopsis hystrix $\times$ Eucalyptus forest & 27 & $14,158.49$ \\
6 & ECTF & Castanopsis hystrixh $\times$ Pinus massoniana forest & 17 & 8547.50 \\
7 & Small business & Eucalyptus forest & 28 & 7555.29 \\
8 & Forest farmer & Eucalyptus forest & 18 & 3473.42 \\
9 & Forest farmer & Cunninghamia lanceolata forest & 9 & 336.04 \\
10 & Forest farmer & Pinus massoniana forest & 9 & 239.32 \\
\hline
\end{tabular}

${ }^{a}$ ECTF is the Experimental Center of Tropical Forests, Chinese Academy of Forest 


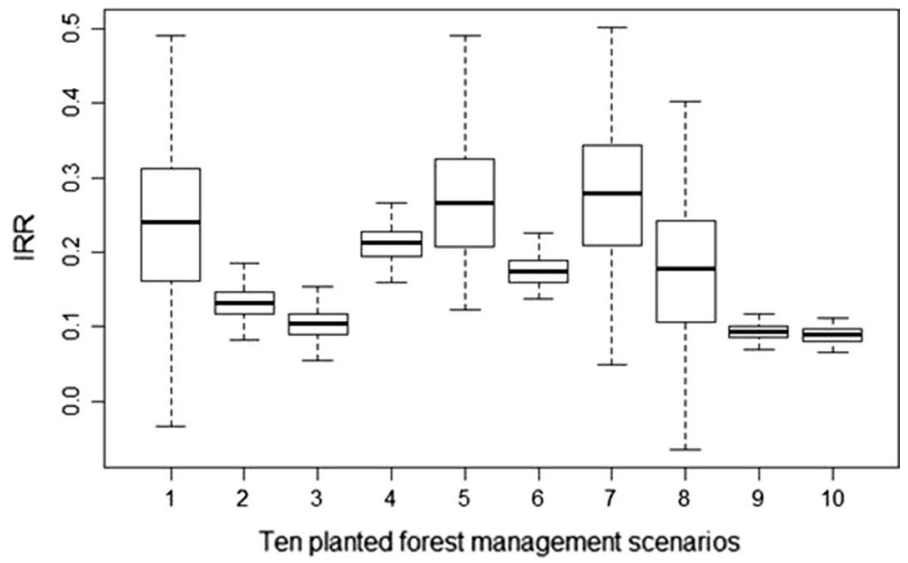

Fig. 1 IRRs of ten planted forest management scenarios. Note: Ten planted forest management scenarios in the horizontal axis were: (1) Eucalyptus forest, ECTF; (2) Cunninghamia lanceolata forest, ECTF; (3) Pinus massoniana forest, ECTF; (4) Castanopsis hystrix forest, ECTF; (5) Castanopsis hystrix $\times$ Eucalyptus forest, ECTF; (6) Castanopsis hystrixh $\times$ Pinus massonianaforest, ECTF; (7) Eucalyptus forest, Small business; (8) Eucalyptus forest, Forest farmer; (9) Cunninghamia lanceolata forest, Forest farmer; (10) Pinus massoniana forest, Forest farmer

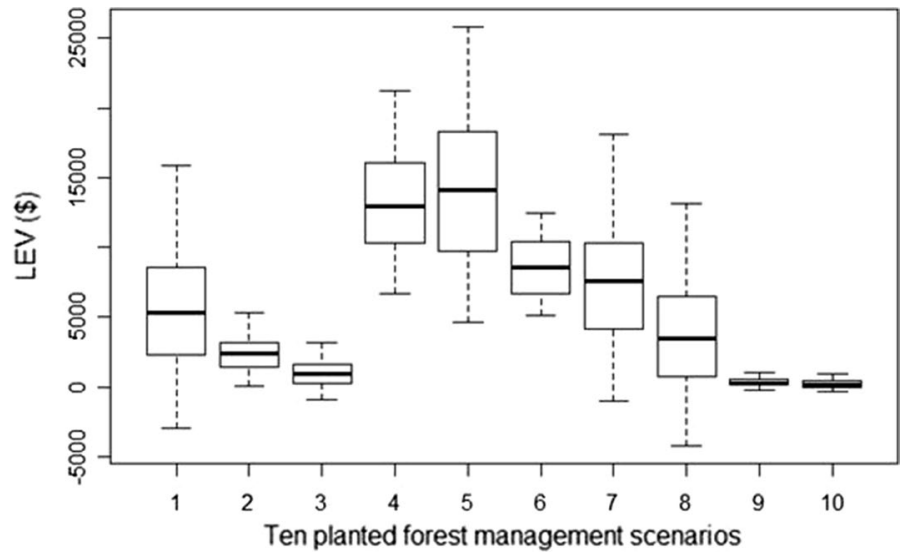

Fig. 2 LEVs of ten planted forest management scenarios. Note: Ten planted forest management scenarios in the horizontal axis were: (1) Eucalyptus forest, ECTF; (2) Cunninghamia lanceolata forest, ECTF; (3) Pinus massoniana forest, ECTF; (4) Castanopsis hystrix forest, ECTF; (5) Castanopsis hystrix $\times$ Eucalyptus forest, ECTF; (6) Castanopsis hystrixh $\times$ Pinus massonianaforest, ECTF; (7) Eucalyptus forest, Small business; (8) Eucalyptus forest, Forest farmer; (9) Cunninghamia lanceolata forest, Forest farmer; (10) Pinus massoniana forest, Forest farmer

that of all planted forest management scenarios. Its IRR could reach $50 \%$ under optimal condition (the cost reduced by $10 \%$, timber price increased by $20 \%$ and timber yield increased by $10 \%)$.

The results for the ECTF indicate that the Eucalyptus forest and Castanopsis hystrix forester returns were greater than those for Cunninghamia lanceolata forest and Pinus massoniana forest, having IRRs of $24 \%, 21 \% 13 \%$ and $10 \%$ per year respectively. The IRR of 


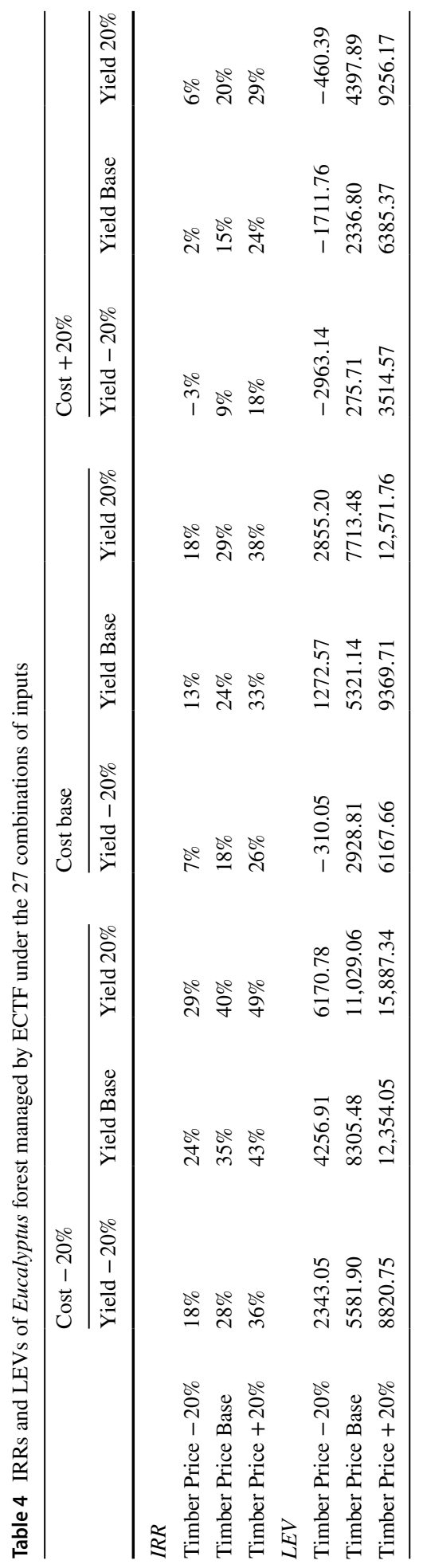


mixed planted forest of Castanopsis hystrix $\times$ Eucalyptus $(27 \%)$ was higher than that of all other scenarios managed by ECTF. The IRR of Castanopsis hystrixh $\times$ Pinus massoniana mixed forest (21\%) was a little less than that of Castanopsis hystrix pure forest, but it was much higher than that of Pinus massoniana pure forest.

For the forest farmers, their Eucalyptus forest returns were greater than those for their Cunninghamia lanceolata forest and Pinus massoniana forest. Their IRR for Eucalyptus forest, Cunninghamia lanceolata forest and Pinus massoniana forest were 18\%, 9\%, and $9 \%$ respectively.

\section{The LEVs of ten planted forest management scenarios}

The LEV by the base data of all the scenarios was greater than zero. A positive LEV indicates that the investors could pay that amount for the land and still receive an $8 \%$ annual, real rate of return. Since the forestland in China was owned by state or collectivity, there was no forestland price anywhere. We collected estimates of forestland rents from the small business and forest farmers in research area, which ranged from $\$ 50$ to $\$ 110$ per year per ha. Considering that the small business always used the same rent to collect large areas of forestland from local forest farmers, we chose this rent (\$75 per ha per year) in our analysis. The imputed land price would be $\$ 1012$ per ha estimated by the formula for Present Value of a Perpetual Annuity at 8\% (the forestland rent serves as the perpetual annuity).

The LEVs of Pinus massoniana forest, regardless of the management entities ECTF (\$948) or forest farmers ( $\$ 239$ per ha), at the $8 \%$ discount rate, were lower than the estimated land price. It means the investment of Pinus massoniana forest could not earn an $8 \%$ annual rate of return with the payment of current land rent. While the Cunninghamia lanceolata forest managed by forest farmers had a lower LEV as well, other scenarios' LEVs were greater than the estimated price of land, but with huge gaps. The higher LEVs were Castanopsis hystrix $\times$ Eucalyptus $(\$ 14,158$ per ha) and Castanopsis hystrix forest $(\$ 13,194$ per ha) managed by ECTF, followed by Eucalyptus forests managed by the small business ( $\$ 7555$ per ha) and Castanopsis hystrix $\times$ Pinus massoniana forest managed by the ECTF ( $\$ 8,547$ per ha). The LEVs of Eucalyptus forests managed by the ECTF ( $\$ 5321$ per ha) and the forest farmer $(\$ 3,473$ per ha) were less, but still quite attractive (Fig. 2$)$. The same general rankings occurred among scenarios with LEVs as with IRRs.

\section{Sensitivity analysis}

Cost, timber price, and timber yield are important factors that determine both IRR and LEV. Table 5 shows that the IRRs and LEVs of Eucalyptus forest managed by ECTF were grouped by each factor's three levels (Table 4). The sensitivity coefficients in Table 6 were calculated by Eq. 4. The final sensitivity coefficients were generated from the Wilcoxon signed-rank test. The $P$ value under a one-sided Wilcoxon signed-rank test of final sensitivity coefficients turned out to be less than the 0.05 significance level. We only listed five test sensitivity coefficients which were close to the final sensitivity coefficients for each variable's one-way change (Table 7). The last lines of Table 7 were the final sensitivity coefficients with their $P$ value. Those numbers then represent the median sensitivity coefficient for the IRR and LEV for the entire series of changes in variables by management regime. The final sensitivity coefficients of other nine management regimes are showed in Figs. 3 and 4 . The similar detailed calculations for each management regime are available as supplementary information by request from the authors. 


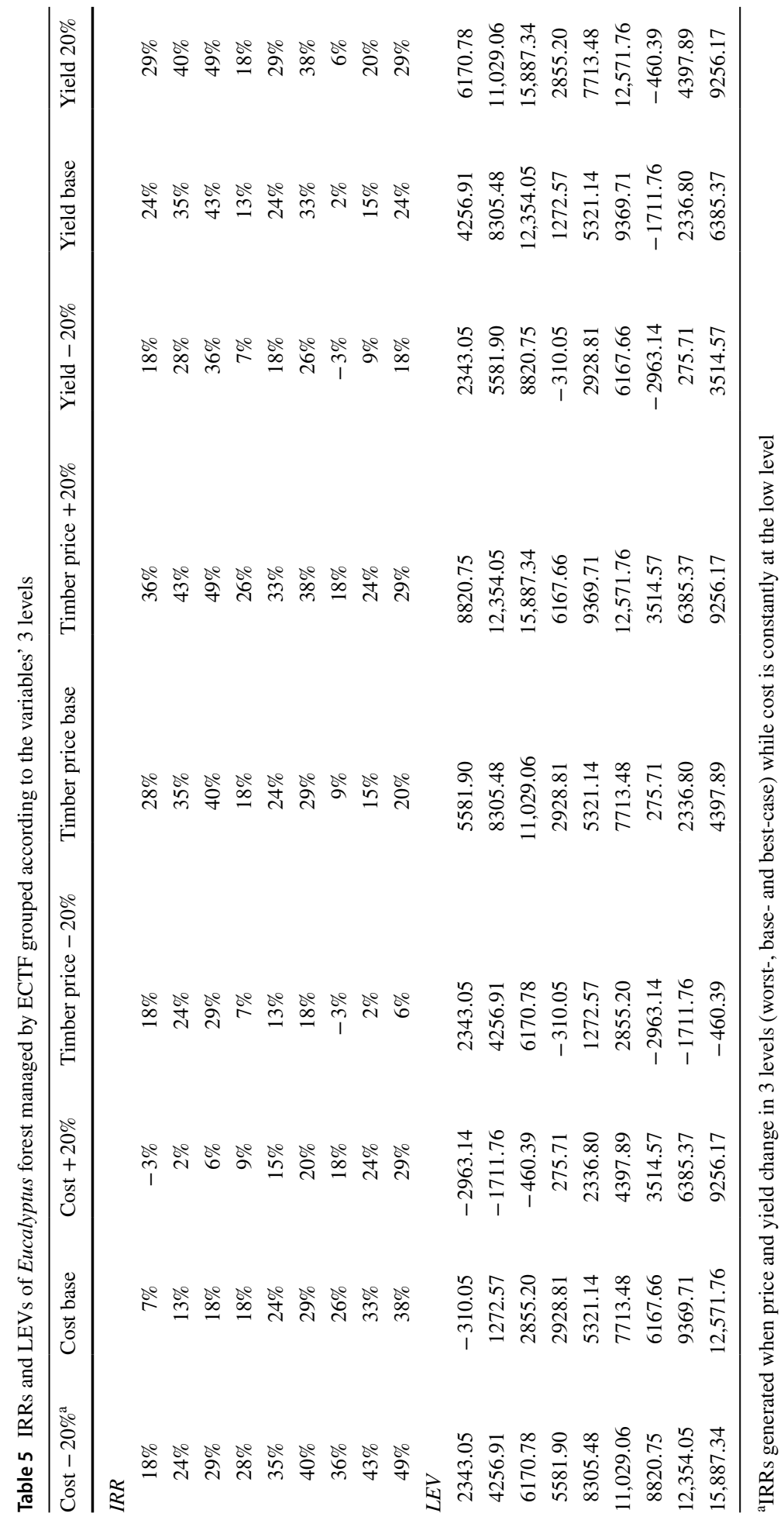


Table 6 Sensitivity coefficients of Eucalyptus forest managed by ECTF

\begin{tabular}{|c|c|c|c|c|c|}
\hline Cost $-20 \%$ & Cost $+20 \%$ & Timber price $-20 \%$ & $\begin{array}{l}\text { Timber price } \\
+20 \%\end{array}$ & Yield $-20 \%$ & Yield $20 \%$ \\
\hline \multicolumn{6}{|l|}{$S(I R R)$} \\
\hline 8.12 & -7.55 & -1.82 & 1.42 & -1.31 & 1.12 \\
\hline 4.56 & -4.24 & -1.53 & 1.20 & -0.98 & 0.83 \\
\hline 3.39 & -3.16 & -1.36 & 1.06 & -0.83 & 0.71 \\
\hline 2.85 & -2.50 & -3.09 & 2.34 & -2.31 & 1.97 \\
\hline 2.20 & -1.93 & -2.39 & 1.80 & -1.31 & 1.12 \\
\hline 1.86 & -1.63 & -2.02 & 1.53 & -1.02 & 0.87 \\
\hline 1.87 & -1.59 & -6.95 & 5.01 & -14.05 & 11.95 \\
\hline 1.55 & -1.33 & -4.36 & 3.14 & -2.00 & 1.70 \\
\hline 1.37 & -1.17 & -3.37 & 2.43 & -1.31 & 1.12 \\
\hline \multicolumn{6}{|l|}{$S(L E V)$} \\
\hline-42.79 & 42.79 & -2.90 & 2.90 & -2.25 & 2.25 \\
\hline 11.73 & -11.73 & -2.44 & 2.44 & -1.64 & 1.64 \\
\hline 5.81 & -5.81 & -2.20 & 2.20 & -1.43 & 1.43 \\
\hline 4.53 & -4.53 & -5.53 & 5.53 & -6.22 & 6.22 \\
\hline 2.80 & -2.80 & -3.80 & 3.80 & -2.25 & 2.25 \\
\hline 2.15 & -2.15 & -3.15 & 3.15 & -1.71 & 1.71 \\
\hline 2.15 & -2.15 & -58.74 & 58.74 & 3.66 & -3.66 \\
\hline 1.59 & -1.59 & -8.66 & 8.66 & -4.41 & 4.41 \\
\hline 1.32 & -1.32 & -5.52 & 5.52 & -2.25 & 2.25 \\
\hline
\end{tabular}

Figure 3 indicates that all the variables were important, but had different magnitudes. The decrease of cost led to remarkable IRR increases for Eucalyptus forest and Castanopsis hystrix $\times$ Eucalyptus forest. With $1 \%$ cost reduction, there were $2.7 \%$ (Eucalyptus forest managed by small business), 1.8\% (Eucalyptus forest managed by ECTF), 1.4\% (Eucalyptus forest managed by forest farmer) and $1.4 \%$ (Castanopsis hystrix $\times$ Eucalyptus forest managed by ECTF) increases in their IRRs. These changes are essentially price elasticities for responses of returns with respect to cost changes. The increase of cost could reduce the returns exactly the same amount of their IRRs as the decrease of cost increased returns. Both changes (decrease/increase of cost) had less effect on the Cunninghamia lanceolata forest (with final sensitivity (elasticity) coefficient $0.7 /-0.5$ for ECTF and $0.2 /-0.2$ for forest farmer), Pinus massoniana forest (0.8/- 0.7 for ECTF and $0.3 /-0.2$ for forest farmer), Castanopsis hystrix forest (0.4/-0.3for ECTF) and Castanopsis hystrixh $\times$ Pinus massoniana forest (0.5/- 0.4 for ECTF).

The increase of timber price was important as well. With $1 \%$ timber price rise, there were $2.1 \%$ (Eucalyptus forest managed by forest farmer), $1.8 \%$ (Eucalyptus forest managed by small business), 1.4\% (Eucalyptus forest managed by ECTF) and 1.3\% (Castanopsis hystrix $\times$ Eucalyptus forest managed by ECTF) increase of their IRRs. However, the decrease of timber price heavily influenced the IRRs of Eucalyptus forest managed by small business (1.4\%) and forest farmer (1.7\%).

Comparing with cost and timber price, timber yield had moderate effect on the IRRs. Except the IRRs of Eucalyptus forest managed by small business, the decline or rise of all the IRRs were less $1 \%$ with the $1 \%$ changes of timber yield. 


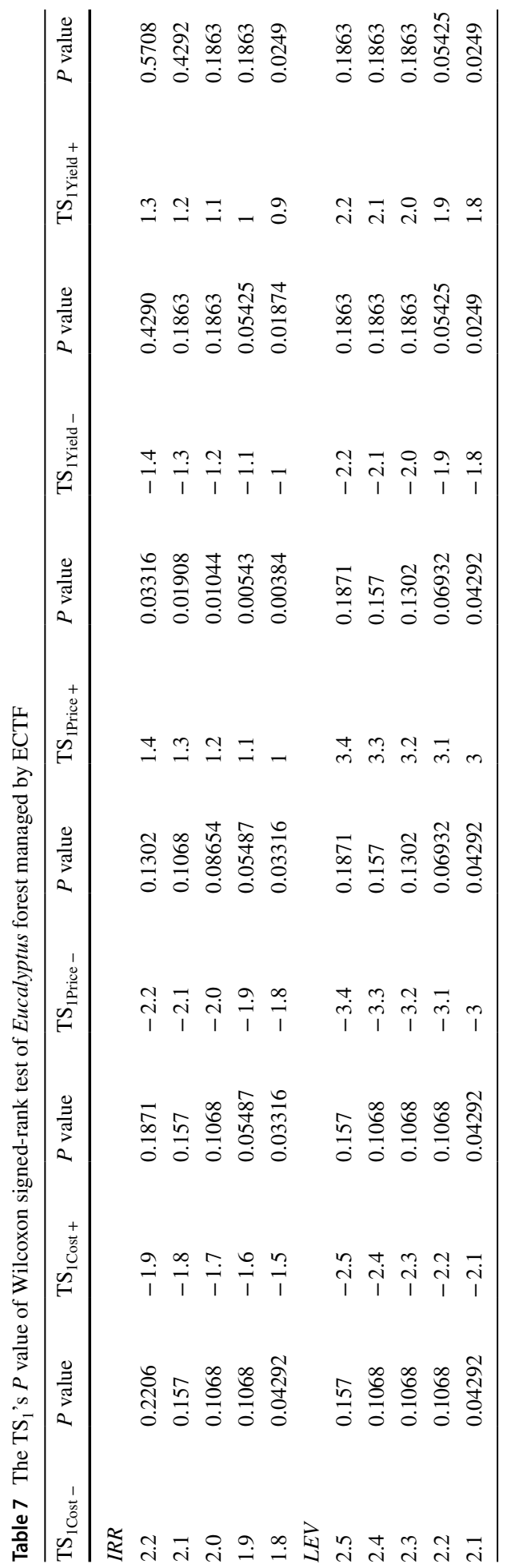




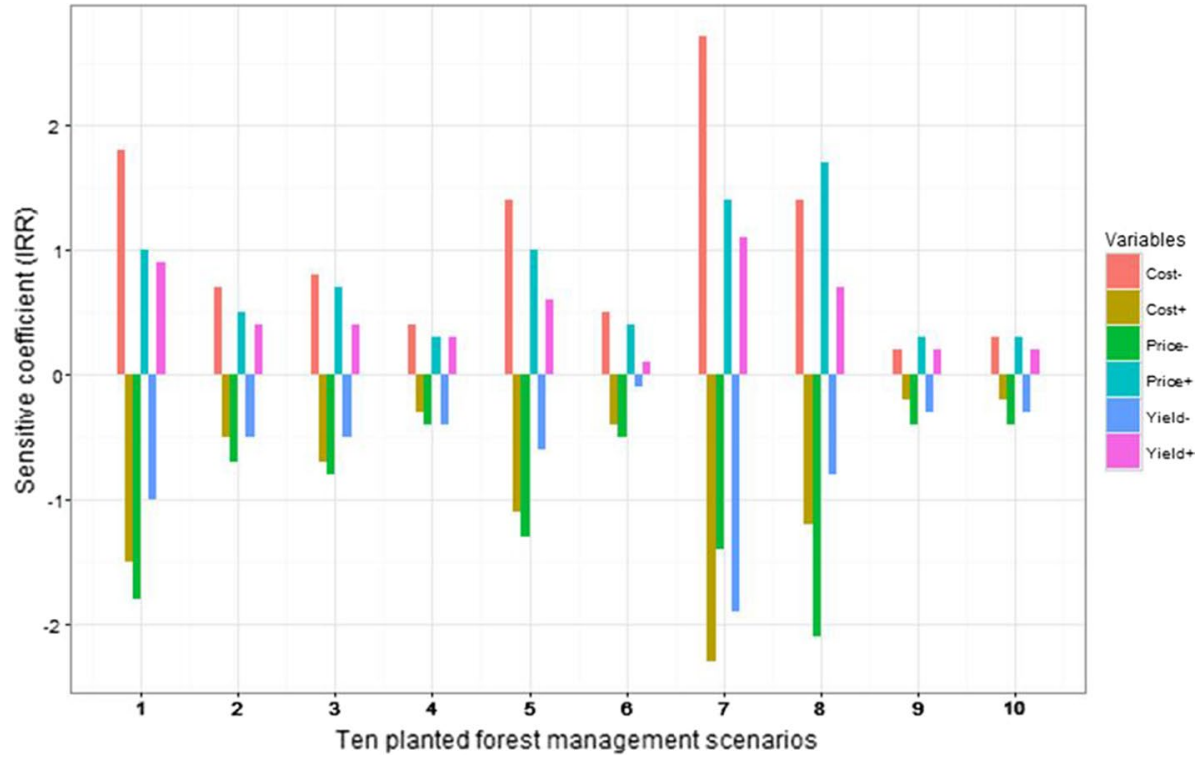

Fig. 3 Final sensitivity coefficient of IRRs. Note: Ten planted forest management scenarios in the horizontal axis were: (1) Eucalyptus forest, ECTF; (2) Cunninghamia Lanceolata forest, ECTF; (3) Pinus massoniana forest, ECTF; (4) Castanopsis hystrix forest, ECTF; (5) Castanopsis hystrix $\times$ Eucalyptus forest, ECTF; (6) Castanopsis hystrixh $\times$ Pinus massoniana forest, ECTF; (7) Eucalyptus forest, Small business; (8) Eucalyptus forest, Forest farmer; (9) Cunninghamia Lanceolata forest, Forest farmer; (10) Pinus massoniana forest, Forest farmer

Generally, the LEVs were more sensitive than IRRs (Fig. 4). Timber price was the strongest factor for the LEVs. For the Eucalyptus forest managed by Forest farmer, its LEV fluctuation ranged from 3.4 times that of the timber price. All the LEVs changed more than $1 \%$ with $1 \%$ changes of timber price.

Both the cost and timber yield greatly influenced the Eucalyptus forests managed by ECTF (2.1/-2.1 and $-1.8 / 1.8$ sensitivity coefficients) and small business (2.6/-2.6 and -3.3/3.3), and Pinus massoniana forest managed by ECTF (2.4/-2.4 and -1.7/1.7). Cost was still the key factor for the Eucalyptus forest managed by forest farmers with the final sensitivity coefficient $1.7 /-1.7$. Timber yield was the most influential factor for the LEVs of Cunninghamia lanceolata forest and Pinus massoniana forest managed by both ECTF and forest farmers.

\section{Discussion}

\section{The efficiency of three management entities}

It is useful to compare the efficiency or profits of the three ownership/land tenure groups by using the returns of Eucalyptus forest, because each of the management entities chose it as their main management models. The small business had the most 


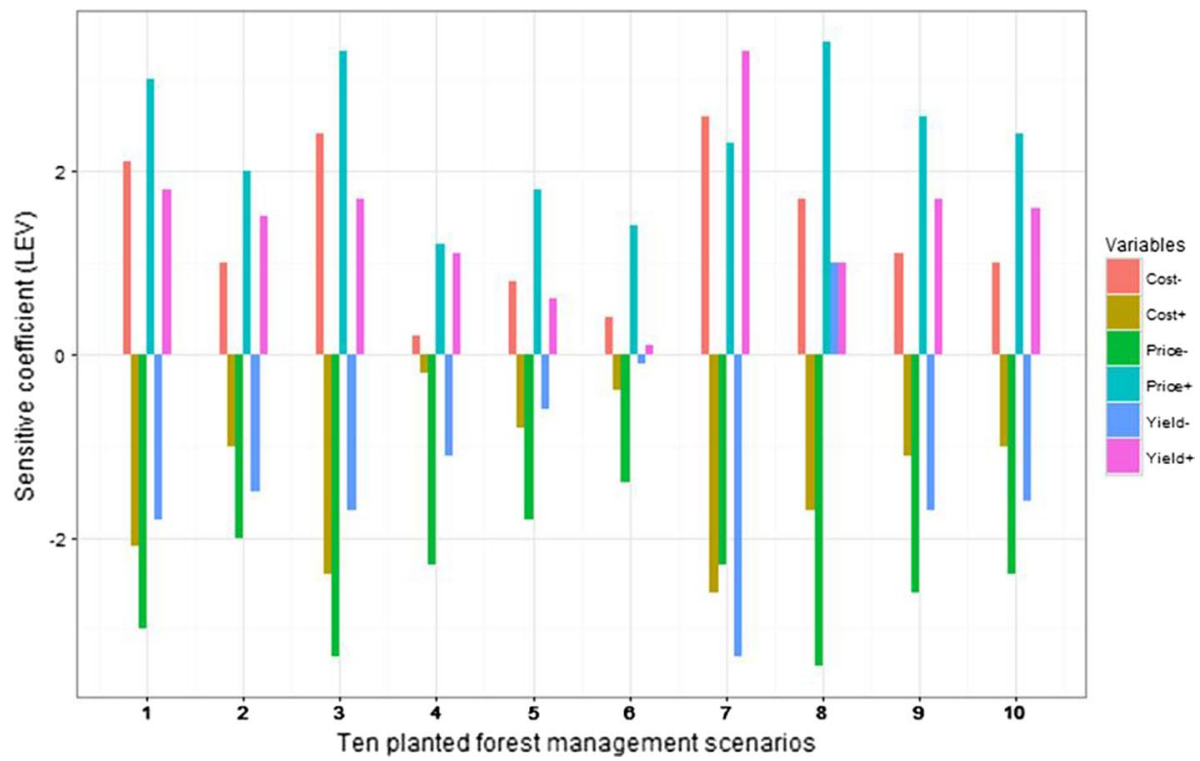

Fig. 4 Final sensitivity coefficients of LEVs. Note: Ten planted forest management scenarios in the horizontal axis were: (1) Eucalyptus forest, ECTF; (2) Cunninghamia Lanceolata forest, ECTF; (3) Pinus massoniana forest, ECTF; (4) Castanopsis hystrix forest, ECTF; (5) Castanopsis hystrix $\times$ Eucalyptus forest, ECTF; (6) Castanopsis hystrixh $\times$ Pinus massoniana forest, ECTF; (7) Eucalyptus forest, Small business; (8) Eucalyptus forest, Forest farmer; (9) Cunninghamia Lanceolata forest, Forest farmer; (10) Pinus massoniana forest, Forest farmer

management efficiency and profits, and ECTF was in the middle. The forest farmers had the least profits.

\section{The small business}

The higher calculated rates of return for small business came from their scale effect and long-term professional management experiences. Some of the small business owners had managed Eucalyptus forest in Fujian and Guangdong Provinces in South China on large scale for many years before this survey, which was helpful to reduce management cost and increase timber yield. The first 5 years' cost of small business for Eucalyptus forest were $\$ 5830$ per ha which was lower than that of forest farmers ( $\$ 6567$ per ha) and ECTF $(\$ 7120$ per ha) (Table 1). The total timber yield of a rotation of small business was the same as the yield of ECTF with $120 \mathrm{~m}^{3}$ per ha, and higher than what the forest farmers harvested, at about $105 \mathrm{~m}^{3}$ per ha.

Although the small businesses had the highest management level compared to the other two planted forest management entities, they were more sensitive to the internal or external factors (Figs. 3, 4). As measured by IRR, changes in returns were influenced mostly by the cost, where the initial costs reduced the IRR. When the fixed $8 \%$ discount rate was used, as indicated by LEV, timber yield was the most sensitive factor. The increase of the cost and decrease of yield may lead to a large loss. At present, their low cost will limit their further increase of income, but their timber yield still had potential to be improved. The MAI of 
Eucalyptus forest can reach up to $25 \mathrm{~m}^{3}$ per ha per year in south China which was higher than that of Eucalyptus forest managed by small business $\left(20 \mathrm{~m}^{3}\right.$ per ha per year, Table 1$)$.

\section{The forest farmers}

Comparing with the ECTF, the forest farmers had low efficiency and returns not only in the management of Eucalyptus forest, but also in Cunninghamia lanceolata forest and Pinus massoniana forest.

Forest farmers were less active with their Cunninghamia lanceolata forest and Pinus massoniana forest which was easy to see from the first 5 years' investment cost (\$755 and $\$ 850$ per ha respectively, Table 1). Their calculated rates of return were lower because of low yield (the MAI was $3.5 \mathrm{~m}^{3} / \mathrm{ha} / \mathrm{yr}$, Table 1 ). The main reasons leading to their low management returns were that they generally had both farmland and forestland. The return of forestland was uncertain and with long management period comparing with farmland, so that they did not rely on Cunninghamia lanceolata forest and Pinus massoniana forest for their livelihoods. Meanwhile, the area of forest farmers' forestland was small and location was remote. It was difficult for them to improve their forest roads and transport their timber out. The net timber price for the forest farmers was less than the market price.

Unlike the management of Cunninghamia lanceolata forest and Pinus massoniana forest, the forest farmers spent more money and paid more attention to the Eucalyptus forest management. Their first 5 years' cost was between the cost of small business and ECTF (Table 1) and their yield was almost the same as small business and ECTF (Table 1).

Based on IRR, the returns of forest farmers' Cunninghamia lanceolata forest and Pinus massoniana forest were stable under the fluctuation of the cost, timber price, and timber yield. This indicates that it is difficult for forest farmers to improve their low level of management without new incentives. Based on LEV at the fixed $8 \%$ discount rate, the returns of their Cunninghamia lanceolata forest, Pinus massoniana forest, and Eucalyptus forest changed most with the fluctuation of timber price. The forest farmer's timber price was lower than the market price, so there was plenty of opportunity for an increase. In addition, the timber price in China will still increase with fluctuations in a small range. This is easy to see from the timber price changes in the local timber market in research area (Fig. 5), and from the huge gap between timber supply and demand in China (Fig. 6).

Fig. 5 The timber price in Pingxiang, Guangxi Province, China. Notes: C: Cunninghamia lanceolata (size: 200-400 $\mathrm{cm} \times 16 \mathrm{~cm})$; E: Eucalyptus (size: 200-260 cm $\times 8-12 \mathrm{~cm}$ ); P: Pinusmassoniana (size: $220-280 \mathrm{~cm} \times 14-18 \mathrm{~cm}$ )

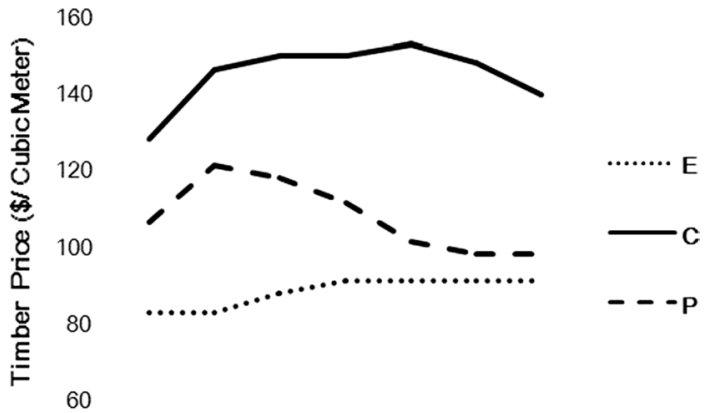

2010201120122013201420152016 
Fig. 6 Timber production, consumption, and net import in China (2005-2014)

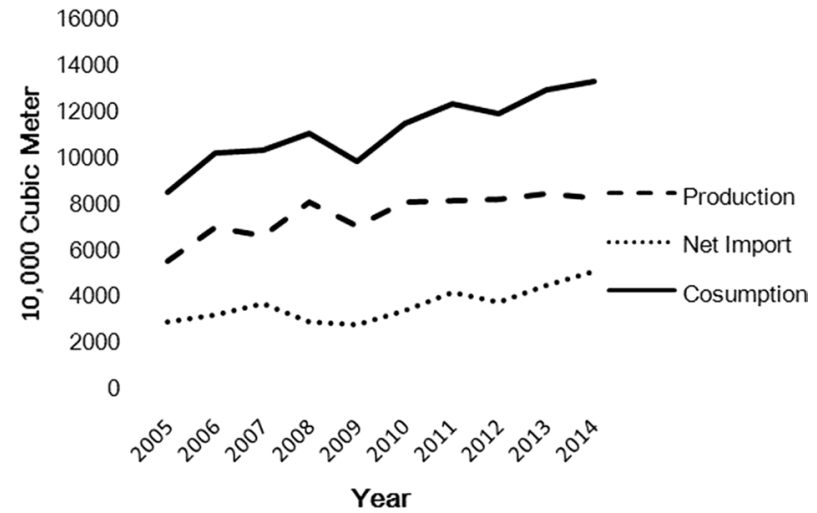

\section{The Experimental Center of Tropical Forestry}

ECTF managed its planted forests not only for economic benefit, but also for experimental research. They managed more diverse planted forest models than any other entities, thus they gave us an opportunity to compare the management models in the same situation and assess which were better than others. The different economic returns and characteristics of ECTF's management models indirectly influence the management decision of small business and forest farmers.

\section{The investment returns of four tree species}

From the result of ECTF above, the Castanopsis hystrix forest had the highest economic returns among the four kinds of pure forest, closely followed by Eucalyptus forest. They had higher calculated rates of return due to high timber prices (the timber price of Castanopsis hystrix was $\$ 334$ per $^{3}$ ) and fast growth rates (the MAI of Eucalyptus forest was $20 \mathrm{~m}^{3} / \mathrm{ha} / \mathrm{yr}$ ). Although the Cunninghamia lanceolata forest's economic return was higher than Pinus massoniana forest because Cunninghamia lanceolata's higher timber price $\left(\$ 150 / \mathrm{m}^{3}\right)$, both of them were much lower than the other two pure forest management models.

The result of sensitivity analysis shows that the IRRs and LEVs of Castanopsis hystrix forest were more stable than those of the other three tree species, which were slightly influenced by cost, timber price and timber yield. It means that the investors who choose the Castanopsis hystrix forest will get high and stable revenue.

The Eucalyptus forest was most sensitive among the four tree species. The cost and timber price were dominant factors leading to the wide range of IRRs for Eucalyptus forest (Fig. 3). For LEV, the cost, timber price and timber yield were all key factors for the revenue. It means that the returns of Eucalyptus forest could be easily increase to a higher level. But it also means that the investment in Eucalyptus forest could be risky.

The IRRs of Cunninghamia lanceolata forest and Pinus massoniana forest were more stable than those of the Eucalyptus forest, but as Eucalyptus forests their LEVs were greatly influenced by three factors. The investments in Cunninghamia lanceolata forest and Pinus massoniana forest were not as good, due to not only the low revenues, but also the risk. 


\section{The economic benefit of two management modes}

The mixed forest could improve the economic returns of pure forest. The economic return of Castanopsis hystrix $\times$ Eucalyptus forest was greater than that of Castanopsis hystrix forest and Eucalyptus forest managed by ECTF. The Castanopsis hystrix $\times$ Pinus massoniana forest improved the economic return of Pinus massoniana forest by a large scale. The mixed forests were more stable than the pure forest. Castanopsis hystrix $\times$ Eucalyptus forest was not as sensitive as Eucalyptus forest to the cost, timber price and timber yield. For the Castanopsis hystrix $\times$ Pinus massoniana forest, it reduced the change ranges of Pinus massoniana forest as well. Changing the pure forest to mixed forest is a way to further increase the economic returns and reduce the risk of Eucalyptus forest.It is also a way to improve the low efficiency of Pinus massoniana forest.

\section{Domestic and abroad comparison}

In China, many places manage planted forests. The economic returns of Cunninghamia lanceolata forest, Pinus massoniana forest and Castanopsis hystrix forest were not much different among regions (Song-Hai et al. 2016). The economic returns of Eucalyptus forest varied by location (Huang 2007). For example, In Fujian Province, which is also an important area for planted forest in Southeast China, the IRR of Eucalyptus forest planted by Yongan Forestry (Group) Co., Ltd, who had begun to manage the Eucalyptus planted forest on large scale since 1994, was 18.1\%. This was lower than the IRR of Eucalyptus forest managed by its counterpart, small business (23\%) in this research (Huang 2007). The IRRs of Eucalyptus forest ranged from 15.4 to $57.1 \%$ in Changtaiyanxi State-owned forest farm in Fujian Province (Wang et al. 2008).

Comparing the planted forest management in other countries, the returns for Eucalyptus forest managed by small business in south China were the same as the Eucalyptus IRR in Brazil (28\%) and more than those in other countries (Argentina, Uruguay, Chile, Colombia, Venezuela, Mexico, Paraguay and Australia) (Cubbage et al. 2014). The intensively managed forest plantations in the southern hemisphere are much more profitable than those in the northern hemisphere (Sedjo 1999). The high economic returns of Eucalyptus forest managed by small business in south China stem from the high timber price (more than 90 $\$ / \mathrm{m}^{3}$ ) in China, caused by the country's fiber supply shortage.

Pinus species returns excluding land costs in this research in South China (ECTF, 10\%; forest farmer, 9\%) were lower than those for Brazil (23\%), Chile (15\%), Uruguay (14\%), Colombia (14\%), Mexico (13\%), Argentina (13\%) and higher than those for Venezuela (8\%), New Zealand (8\%), USA (8\%), and Australia (7\%) (Cubbage et al. 2014).

\section{Conclusion}

This research shows the diversity and economic returns of planted forest management in China. These results indicate that small business in China was the most efficient forest managers by tenure type. The economic return of their Eucalyptus forest for small businesses was the same as that in Brazil, but had a high risk with fluctuations of cost, timber price, and timber yield. The Experimental Center of Tropical Forestry provided more forest management regimes for analysis, such as Castanopsis hystrix forest, Castanopsis hystrix $\times$ Eucalyptus forest and Castanopsis hystrix $\times$ Pinus massoniana forest, which had 
the features of high profits and low risks. The results indicate that forest farmers had the lowest level of returns for the case of Eucalyptus forest management in South China, but it was still in the middle rank of global comparisons. The Cunninghamia lanceolata forest and Pinus massoniana forest management in China were less competitive, but they all had IRRs greater than $8 \%$ without land costs.

With land costs, the IRRs would be lower. We had information on land rent from small business and estimate the imputed land price $\$ 1012$ per ha. Except Pinus massoniana forest and Cunninghamia lanceolata forest, all scenarios' LEVs were greater than the estimated price of land. Thus we could expect to make profits with forest plantation investments by renting forest land and growing timber at an $8 \%$ discount rate in most scenarios, but there were differences in profits.

The planted forest in China with higher derived stumpage prices (more than $\$ 90 / \mathrm{m}^{3}$ ) do have higher rates of return. The higher timber price in China was caused by its fiber supply shortage, and it will still increase with fluctuations in a small range in the future. For the Eucalyptus forest, the timber price was its most sensitive factor. Thus the returns of Eucalyptus forest could easily increase to a higher level with the rise of timber price. But it also means that the investment in Eucalyptus forest in China could be risky.

It was interesting that the sensitivity of the ranking of results did differ somewhat by capital budgeting criteria, as suggested by the forestry literature (e.g., Klemperer 1996; Wagner 2012), but not occurring that often. IRR changes were affected more by planting costs, which occured early in the rotation. Changes in LEV returns were affected more by the timber prices, which occurred at sale time. This is exactly why LEV is preferred if one knows their fixed discount rate- the preferred financial objective is to maximize real cash profits at a given discount rate, not the internal rate of return.

In order to achieve the highest rates of return at the stand level, for both small business and forest farmer in South China, it is good to introduce precious native tree species in their management, such as Castanopsis hystrix forest, or change their pure forest to mixed forest, such as Castanopsis hystrix $\times$ Eucalyptus forest and Castanopsis hystrix $\times$ Pinus massoniana forest. Those choices reduced the risk as well, as the precious native tree species and mixed forest were not sensitive under the most likely fluctuation of the cost, timber price and timber yield.

For the small business in China, there was still opportunity to improve their Eucalyptus forest's economic returns. They could further improve the IRR by reducing the cost and the LEV by increasing the timber yield. Both of these factors were sensitive factors for the small business' Eucalyptus forest management. In addition, most of the forest land contracts in China were less than 30 years, so that changing to long-cycle tree species was impossible for some small businesses. Small business in China depended more on the Eucalyptus forests, whose further management improvement through genetics, nurseries, and silviculture need more research development, and implementation.

Many forest farmers in South China with Pinus massoniana forest and Cunninghamia lanceolata forest had low economic returns. Besides changing to precious native tree species and mixed forest, renting out their forestland to the small business is a good choice as well, which was promoted by the central and local government after the Collective Forest Tenure Reform. It could solve the problem of low efficiency of forestland utility and the forestland fragmentation. What's more, improving the forest roads could increase forest farmers' derived timber stumpage price, making it closer to the market timber price, and then increasing their revenues.

In addition, cost was a considerable influence for the financial returns of planted forests investments. In the further research, we could calculate the planted forest investment 
returns under the fluctuation of all part of cost, such as the cost of site preparation, planting, periodic stand treatments, harvest and management, so as to find out the details that influence the investment returns most. This will make the estimates of planted forest management returns in South China more robust. However, the base level returns we calculated were quite substantial, so our results should be reliable. They do provide detailed comparisons based on extensive empirical data sets among the three principal types of forest ownership in southern China.

Acknowledgements This research was supported by the National Key R \& D Program (No. 2017YFC0504502), National Special Research Program for Public-Welfare Forestry Project (No. 200904005), and the Project on Introducing Internationally Advanced Forest Science and Technology (No. 2012-4-69).

Open Access This article is distributed under the terms of the Creative Commons Attribution 4.0 International License (http://creativecommons.org/licenses/by/4.0/), which permits unrestricted use, distribution, and reproduction in any medium, provided you give appropriate credit to the original author(s) and the source, provide a link to the Creative Commons license, and indicate if changes were made.

\section{References}

Ainembabazi JH, Angelsen A (2014) Do commercial forest plantations reduce pressure on natural forests? Evidence from forest policy reforms in Uganda. For Policy Econ 40:48-56

Bai G, Wang Y, Dai L, Liu S, Tang L, Shao G (2015) Market-oriented forestry in China promotes forestland productivity. New For 46:1-6

Ben-Horin M, Kroll Y (2017) A simple intuitive NPV-IRR consistent ranking. Q Rev Econ Finance 1:1-7

Chen P (2001) The confirmation of harvesting period and the analysis of economic effect on the productive and high-quality chinese fir plantation. Sci Silvae Sin 31:47-51

Chen S, Zhou G, Lin Y (2002) Rotation of Eucalyptus grandis $\times$ E. urophylla plantation for pulp and paper. For Res 15:394-398

Cubbage F, Donagh PM, Júnior JS, Rubilar R, Donoso P, Ferreira A, Hoeflich V, Olmos VM, Ferreira G, Balmelli G, Siry J, Báez MN, Alvarez J (2007) Timber investment returns for selected plantations and native forests in South America and the Southern United States. New For 33:237-255

Cubbage F, Koesbandana S, Donagh MP, Rubilar R, Balmelli G, Olmos VM, Torre RDL, Murara M, Hoeflich VA, Kotze H, Gonzalez R, Carrero O, Frey G, Adams T, Turner J, Lord R, Huang J, MacIntyre C, McGinley K, Abt R, Phillips R (2010) Global timber investments, wood costs, regulation, and risk. Biomass Bioenergy 34:1667-1678

Cubbage F, Davis R, Frey G, Behr D (2013) Financial and economic evaluation guidelines for community forestry projects in Latin America Program on Forests (PROFOR), Washington, DC

Cubbage F, Donagh PM, Balmelli G, Olmos VM, Bussoni A, Rubilar R, Torre RDL, Lord R, Huang J, Hoeflich VA, Murara M, Kanieski B, Hall P, Yao R, Adams P, Kotze H, Monges E, Pérez CH, Wikle J, Abt R, Gonzalez R, Carrero O (2014) Global timber investments and trends, 2005-2011. N Z J For Sci 44(Suppl 1):S7. http://www.nzforestryscience.com/content/4451/s7. Accessed 5 Dec 2014

Dai L, Zhao W, Shao G, Lewis BJ, Yu D, Zhou L, Zhou W (2013) The progress and challenges in sustainable forestry development in China. Int J Sustain Dev World Ecol 20:394-403

Evison D (2018) Estimating annual investment returns from forestry and agriculture in New Zealand. J For Econ. https://doi.org/10.1016/j.jfe.2018.06.001

Food and Agriculture Organization (FAO) (2013) Forest tenure reform in China. http://www.fao.org/docre p/018/mi285e/mi285e.pdf. Accessed 1 May 2017

Frey GE, Cubbage FW, Ha TTT, Davis RR, Carle JB, Thon VX, Dzung NV (2018) Financial analysis and comparison of smallholder forest and state forest enterprise plantations in Central Vietnam. Int For Rev 20:181-198

He H, Xu J (2011) Projection of timber supply and demand trends in China based on an econometric model. For Prod J 61:543-551

Hou YL, Wang CH, Wu J, Wen YL (2013) A theoretical analysis of forestland scale management in collective forest areas of south China. J Beijing For Univ (Soc Sci) 12(4):1-6 
Huang H (2007) Evaluation of investment economic revenue and confirmation of the best economic cutting cycle of industrial raw material forest eucalyptus. Sci Silvae Sin 6:128-134

Ibbotson RG, Sinquefield RA (1976) Stocks, bonds, bills and inflation: year-by-year historical returns (1926-1974). J Bus 49:11-47

Jiang S, Lewis BJ, Dai L, Jia W, An Y (2014) The reform of collective forest rights in China and its implementation in the Fushun City Region. Ann For Res 57:319-332

Jiang J, Lu Y, Pang L, Liu X, Cai D, Xing H (2015) Short-term effects of the management intensities on structure dynamics in monoculture forests of southern subtropical China. Trop Conserv Sci $8(1): 187-200$

Keča L, Keča N, Pantić D (2012) Net present value and internal rate of return as indicators for assessment of cost-efficiency of poplar plantations: a Serbian case study. Int For Rev 14:145-156

Klemperer WD (1996) Forest resource economics and finance. Land Econ 73:440

Liao XC, Zhang YQ, Sun CY (2009) Investments in timberland and softwood timber as parts of portfolio selection in the United States: a cointegration analysis and capital asset pricing model. For Sci 55:471-479

Liu S, Wu S, Hui W (2014) Managing planted forests for multiple uses under a changing environment in China. N Z J For Sci 44:1-10

Macdicken K, Jonsson Ö, Piña L, Maulo S, Adikari Y, Garzuglia M, Lindquist E, Reams G, D’Annunzio R (2015) Global forest resources assessment 2015: how are the world's forests changing?. Agriculture Organization of the United Nations, Rome

Maraseni TN, Son HL, Cockfield G, Duy HV, Nghia TD (2017) Comparing the financial returns from acacia plantations with different plantation densities and rotation ages in Vietnam. For Policy Econ 83:80-87

National Bureau of Statistics (2014) Chinese Statistic Almanac of 2013. China Statistics Press, Beijing

Payn T, Carnus J-M, Freer-Smith P, Kimberley M, Kollert W, Liu S, Orazio C, Rodriguez L, Silva LN, Wingfield MJ (2015) Changes in planted forests and future global implications. For Ecol Manag 352:57-67

Qin P, Carlsson F, Xu J (2011) Forest tenure reform in china: a choice experiment on farmers' property rights preferences. Land Econ 87:473-487

Rocha AG (1973) J. Price Gittinger. Economic analysis of agricultural projects. The Johns Hopkins University Press, Baltimore

Salek L, Sloup R (2012) Economic evaluation of proposed pure and mixed stands in Central Vietnam highlands. J Agric Rural Dev Trop Subtrop 113:21-29

Secco LD, Pirard R (2015) Do tree plantations support forest conservation? CIFOR Infobrief 1:1-8

Sedjo RA (1983) The comparative economics of plantation forestry: a global assessment. Resources for the Future. Johns Hopkins Press, Baltimore

Sedjo RA (1999) The potential of high-yield plantation forestry for meeting timber needs. New For 17:339-360

Sedjo RA (2001) The role of forest plantations in the world's future timber supply. For Chron 77:221-225

Sewall (2014) Global trade in wood fiber. Sewall Insights 4:1-6

Shaoming YE, Zheng X (2006) Study on current situation and management strategy of eucalyptus plantation in Guangxi. For Resour Manag 6:24-27

Song-Hai LI, Jiang JL, Min WU (2016) Economic benefit evaluation of 29-year-old Castanopsis hystrix plantation. J South Agric 47:984-988

State Forestry Administration (SFA) (2013a) Construction plan of national timber strategic storage and production bases (2013-2020). China Forestry Publishing, Beijing

State Forestry Administration (SFA) (2013b) The 8th national forestry inventory results. China Forestry Publishing, Beijing

State Forestry Administration (SFA) (2015) Forestry Statistic Almanac. China Forestry Publishing, Beijing

Taheri SM, Hesamian G (2013) A generalization of the Wilcoxon signed-rank test and its applications. Stat Pap 54:457-470

Tee J, Scarpa R, Dan M, Guthrie G (2014) Forest valuation under the New Zealand emissions trading scheme: a real options binomial tree with stochastic carbon and timber prices. Land Econ 90:44-60

Wagner JE (2012) Forestry economics: a managerial approach. Routledge, New York

Wang LC (2010) Discussion on methods of various rates definition in assessment of forest resource assets. For Inventory Plan 34:68-70

Wang BN, Zhang YY, Tang JF, Chen JY, Wang HB (2008) Economic benefit analysis of different eucalyptus clones. For Prospect Des 2:19-23

Wang YY, Bai GX, Shao GF, Cao YK (2014) An analysis of potential investment returns and their determinants of poplar plantations in state-owned forest enterprises of China. New For 45:251-264 
Xin-Min QI, Ding GJ, Wang DL, Luo QJ (2001) Analysis on economic performance of pinus massoniana forest for pulpwood with different cultivation technique. J Zhejiang For Sci Technol 21:69-73

Xu J, Jiang X (2009) Collective forest tenure reform in China: outcomes and implications. https://www.fig. net/resources/proceedings/2009/fig_wb_2009/papers/trn/trn_1_xu.pdf. Accessed 19 Mar 2017

Youjun HE, Liang X, Qin L, Zhiyong LI, Shao M (2013) Community characteristics and soil properties of coniferous plantation forest monocultures in the early stages after close-to-nature transformation management in southern subtropical China. Acta Ecol Sin 33:2484-2495

Zhang Y, Song C (2006) Impacts of afforestation, deforestation, and reforestation on forest cover in China from 1949 to 2003. J For 104:383-387

Zhen Z, Xu Z, Shen Y, Huang C (2018) How forestland size affects household profits from timber harvests: a case-study in China's Southern collective forest area. https://doi.org/10.1016/j.landusepol .2018.04.055. Accessed 19 Dec 2018

Publisher's Note Springer Nature remains neutral with regard to jurisdictional claims in published maps and institutional affiliations.

\section{Affiliations}

\section{Pu Zhang ${ }^{1} \cdot$ Youjun $\mathrm{He}^{2} \cdot$ Yiming Feng ${ }^{1} \cdot$ Rafael De La Torre $^{3} \cdot$ Hongyan Jia $^{4}$. Jixin Tang ${ }^{5} \cdot$ Frederick Cubbage $^{6}$}

$\mathrm{Pu}$ Zhang

zhangpucaf@163.com

Youjun $\mathrm{He}$

heyoujun@caf.ac.cn

Yiming Feng

fengym@caf.ac.cn

Rafael De La Torre

rdelat@hotmail.com

Hongyan Jia

rlzxjhy@163.com

Jixin Tang

tangjixin999@126.com

1 Institute of Desertification Studies, Chinese Academy of Forestry, Huaishuju Road 10\#, Haidian District, Beijing 100091, China

2 Research Institute of Forestry Policy and Information, Chinese Academy of Forestry, Dong Xiaofu 2\#, Xiangshan Road, Haidian District, Beijing 100091, China

3 Arbor Gen, 2011 Broadbank Court, Ridgeville, SC 29472, USA

4 The Experimental Center of Tropical Forestry, Chinese Academy of Forestry, Keyuan Road, Pingxiang 532600, Guangxi, China

5 The Experimental Center of Tropical Forestry, Chinese Academy of Forestry, Beida Road, Pingxiang 532600, Guangxi, China

6 Department of Forestry and Environmental Resources, North Carolina State University, Box 8008, 3118B Jordan Hall, 2800 Faucette Blvd., Raleigh, NC 27695-8008, USA 